\title{
THE INCIDENCE AND LIFE EXPECTATION OF CHILDREN WITH CONGENITAL HEART DISEASE
}

\author{
BY \\ BRIAN MACMAHON, ${ }^{*}$ THOMAS McKEOWN, AND R. G. RECORD
}

From the Department of Social Medicine, University of Birmingham

Received August 12, 1952

An acceptable estimate of the incidence of congenital heart disease in the general population of births is not yet available. Observations recorded at birth on series of consecutive births have given figures that are clearly much too low, which is scarcely surprising in view of the uncertainty of diagnosis in the newborn. Malpas (1937) found only 10 patients with heart defects among 13,964 births (0.7 per thousand) and DePorte and Parkhurst (1945) noted 142 in 300,795 births $(0.5$ per thousand). Estimates of incidence in patients examined post mortem (reported by Leech, 1935; and Potter, 1940; among many others) or in patients admitted to hospitals (Roberts, 1937; Thordarson, 1947) vary widely, and are equally unsatisfactory as indices of incidence in all births. Perhaps the most reliable data have been derived from examination of school children, for whom Sampson et al. (1938), Rauh (1939) and Weiss (1941) gave estimates between 0.14 and 0.16 per thousand. These figures are of course unacceptable as an expression of incidence in the general population of births. Data recorded in the Registrar-General's Statistical Review of England and Wales indicate that the majority of deaths attributed to congenital heart disease occur before the end of the first year of life, and even when allowance is made for errors in certification it can hardly be doubted that early mortality is very high.

There is no reliable information about the life expectation at birth of affected children. Survival rates have, however, been examined for selected individuals who survived for some time after birth, for example by Ash and Harshaw (1939) for grouped cardiac malformations, and by Benn (1947) for patent ductus arteriosus.

In the present communication we record estimates of incidence and life expectation' at birth based on all cases of congenital heart disease (633) identified at birth or later in a population of 199,418 total births. The main sources of error are $(a)$ erroneous certification of cause of death in children who died without post-mortem examination or adequate clinical investigation, and (b) incomplete recording of children with minor malformations who survived. Reasons are given for believing that these errors are unlikely to prejudice seriously the reliability of the estimates.

Materials. We have attempted to obtain information about all cases of congential heart disease born in the years 1940-49 to mothers domiciled within the administrative boundary of Birmingham. Data were collected from the following sources.

(1) Records of all post-mortem examinations conducted in maternity, pædiatric, and general hospitals in the city.

(2) Clinical records of all patients seen by consultant physicians or surgeons in the same hospitals.

(3) Records of all patients attending special schools or under the supervision of school medical officers in ordinary schools.

(4) Local Authority registers of stillbirths and neonatal and infant deaths.

There were 633 cases which are classified in Table I according to the method of diagnosis.

* In receipt of a grant from the Medical Research Council. 
TABLE I

Method of Diagnosis of Congenital Heart Disease in 633 Patients Born in Birmingham, 1940-49

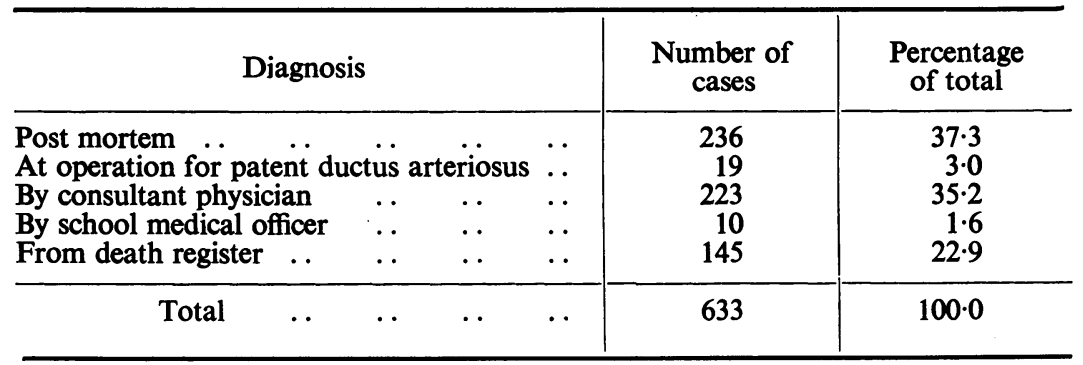

The method of diagnosis is the most reliable of the alternatives available: for example, of 63 patients reported by school medical officers, 47 are shown under " by consultant physician," and 6 under " by operation for patent ductus arteriosus"; and of 355 cases in Local Authority infant death registers, 210 were confirmed by an alternative and more reliable source of information. Of the 223 cases in which the diagnosis rested on the opinion of a consultant $168(75 \%)$ were seen at the Birmingham Children's Hospital. The diagnosis of the specific cardiac defect is given in Appendix A for 255 patients examined post mortem or at operation for patent ductus arteriosus, and in Appendix B for 117 of the 223 patients examined by consultants. In the remaining 106 cases seen by consultants (and not submitted to operation or post mortem) no specific diagnosis was made.

\section{INCIDENCE}

Table II gives the incidence of congenital heart disease in Birmingham (1940-49) as 3.2 per thousand total births. For the years 1940-44, when because of the longer period of observation ascertainment was more complete than in later years, incidence was 3.6 per thousand total births, and 3.7 per thousand live births. We may now consider briefly to what extent these estimates are likely to be affected by errors of observation.

(a) Incidence in Stillbirths (5 in 5202 or 1.0 per thousand). During the period of enquiry less than half of all Birmingham stillbirths were submitted to post-mortem examination, without which

TABLE II

Incidence of Congenital Heart Disease

\begin{tabular}{l|c|c|c}
\hline Year & $\begin{array}{c}\text { No. of } \\
\text { cases }\end{array}$ & $\begin{array}{c}\text { Related } \\
\text { total births }\end{array}$ & $\begin{array}{c}\text { Incidence per } \\
1000 \text { total } \\
\text { births }\end{array}$ \\
\hline 1940 & 55 & 16,424 & $3 \cdot 4$ \\
1941 & 40 & 14,508 & $2 \cdot 8$ \\
1942 & 68 & 18,200 & $3 \cdot 7$ \\
1943 & 90 & 19,911 & $4 \cdot 5$ \\
1944 & 78 & 22,285 & $3 \cdot 5$ \\
1945 & 63 & 19,685 & $3 \cdot 2$ \\
1946 & 48 & 22,717 & $2 \cdot 1$ \\
1947 & 79 & 24,577 & $3 \cdot 2$ \\
1948 & 52 & 20,999 & $2 \cdot 5$ \\
1949 & 60 & 20,112 & $3 \cdot 0$ \\
\hline Total & $633 *$ & $199,418 \dagger$ & $3 \cdot 17$ \\
\hline
\end{tabular}

* 5 stillbirths; 628 livebirths.

† 5202 stillbirths; 194,216 livebirths. 
the diagnosis is of course quite unreliable. Incidence can be estimated from results of post-mortem examinations of consecutive stillbirths, and by combining data reported by Browne (1924), Rannels and Propst (1937), Evans and Smith (1946) and Morison (1952) we have obtained a figure of 3 per thousand ( 3 cases in 984 stillbirths). [A series recorded by Jacobius and Moore (1938) gives a much higher incidence (17 cases in 335 stillbirths), but we have not included it because the findings are at variance with those from other sources.] On the available evidence it seems probable that congenital malformation of the heart is not a common cause of stillbirth (Potter, 1938), and the incidence in stillbirths may be little higher than in all births. If this is the case approximately 15 malformations might have been expected among the 5202 stillbirths notified in Birmingham in the years $1940-49$, which suggests that about 10 have been missed.

(b) Incidence in Livebirths (628 in 194,216, or 3.2 per thousand). There are three obvious sources of error in estimating incidence in livebirths.

(i) Deaths wrongly attributed to congenital heart disease. We can probably accept the certification of cause of death as reasonably reliable in cases submitted to necropsy (236) or examined by a consultant physician (59). It is with the diagnosis in the 145 infants recorded in the infant death register who died without adequate clinical or post-mortem examination that serious difficulty appears. All of these deaths occurred within the first year of life (93 within the first week) and it seems quite certain that in some of them cause of death was incorrectly diagnosed. Table III gives the distribution of the 145 cases according to place of birth and age at death, and strongly

TABLE III

Distribution by Place of Birth and Age at Death of 145 Unconfirmed Cases Recorded FROM THE DEATH REGISTER

\begin{tabular}{l|c|c|c|c}
\hline \multirow{2}{*}{ Age at death } & \multicolumn{3}{|c|}{ Place of birth } & \multirow{2}{*}{ Total } \\
\cline { 2 - 4 } & Hospital & At home & $\begin{array}{c}\text { Nursing home } \\
\text { or unknown }\end{array}$ & \\
\hline & & & & \\
- 3 days & $4(21)$ & $60(71)$ & $4(8)$ & $68(100)$ \\
- 1 week & $7(21)$ & $16(23)$ & $2(6)$ & $25(50)$ \\
- 3 month & $4(23)$ & $9(33)$ & $7(19)$ & $20(75)$ \\
- 1 year & $4(17)$ & $8(29)$ & $3(11)$ & $15(57)$ \\
\hline \multicolumn{1}{c|}{ Total } & $5(24)$ & $7(42)$ & $5(7)$ & $17(73)$ \\
\hline
\end{tabular}

Numbers in brackets are the total numbers of registered deaths in which the diagnosis was confirmed or unconfirmed.

suggests that a number of deaths of children delivered at home were wrongly attributed to congenital heart disease. It seems unlikely that the incidence of affected would be higher in domiciliary than in hospital births (the incidence of congenital heart disease does not appear to be associated with maternal age or birth order, MacMahon, 1952), and, indeed, among the 212 children who died after the third day of life the proportion of hospital deliveries $(40 \% *)$ is approximately the same as among 1086 controls $(41 \% *)$ considered to be representative of all births in the city. But of the 92 children who died within the first three days, 71 were delivered at home, which is roughly 40 in excess of the number expected (31) assuming the relative proportions of domiciliary and hospital births to be the same in children who died before and after three days. In 60 of the 71 cases the diagnosis was unconfirmed. It is of course possible that children with congenital heart disease receive less effective treatment and consequently die earlier if born at home, but it seems much

* These estimates are based on the total number of births in hospital or at home, which excludes births in nursing homes, or for which place of delivery was unknown. 
more likely that the high incidence of early domiciliary deaths from this cause is explained by errors in diagnosis.

If, therefore, we accept the incidence of first-year deaths in hospital births (of which the majority were confirmed post mortem) as reasonably reliable and assume that the incidence is roughly the same in domiciliary as in hospital births, the data suggest that the number of registered deaths is about 40 more than it should be. These 40 will be included among the 100 domiciliary births in which the diagnosis was unconfirmed.

(ii) Omission of patients who died without recognition of a congenital heart lesion. There is no means of assessing the number of cases lost in this way, but it seems unlikely that it is large.

(iii) Omission of patients who had not come to medical attention at the time of enquiry. We have no information about the incidence of cardiac malformations in children who survived more than 11 years without coming to medical attention. Moreover, for most of the 633 cases the length of the history is much less than 11 years, and for children born in 1949 it is less than 3 years (the enquiry was completed in January, 1952). By using the data available for the earlier years to give an expected incidence in the later years an estimate has been made of the number of cases lost because the histories were less than 11 years. Forty-two affected appear to have been lost for this reason.

To sum up: examination of the data upon which the estimate of incidence of congenital heart disease is based suggests that approximately: (a) 10 stillborn affected have been missed; (b) 40 first-year deaths were wrongly attributed to congenital heart disease; and (c) 42 more affected children would have been discovered if an 11-year history had been available in all cases. No estimate is made of numbers of deaths of affected not attributed to congenital heart disease; and patients who left the area or who reached the age of 11 without being identified. On the whole it seems probable that the estimated incidence $(3 \cdot 2$ per thousand total births) slightly understates the true incidence.

\section{SuRvival}

Table IV gives estimated death rates according to age, based on 628 liveborn children with congenital heart disease. The method of estimation is as follows. From the number of patients known to be alive at the beginning of each period (column 1) is subtracted the number lost (column 2) for reasons other than death during that period (for example patients lost sight of, or patients who had not reached the end of the age interval under consideration at the time of enquiry). The number subtracted is corrected for that proportion of the interval for which each patient's history is incomplete; this gives the number at risk of death during the age interval (column 3 )

TABLE IV

Estimated Death Rates According to Age of Liveborn Children with Congenital Heart Disease

\begin{tabular}{|c|c|c|c|c|c|c|}
\hline Age period & & $\begin{array}{c}1 \\
\text { Number known } \\
\text { to be alive at } \\
\text { beginning of } \\
\text { each period }\end{array}$ & $\begin{array}{c}\text { 2 } \\
\text { Number lost } \\
\text { for reasons } \\
\text { other than } \\
\text { death }\end{array}$ & 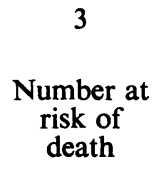 & $\begin{array}{c}4 \\
\begin{array}{c}\text { Number of } \\
\text { deaths }\end{array}\end{array}$ & $\begin{array}{c}5 \\
5 \\
\begin{array}{c}\text { Death rate } \\
\text { (per cent) }\end{array}\end{array}$ \\
\hline $\begin{array}{l}\text { Birth -.. } \\
1 \text { day - } \\
1 \text { week - } \\
1 \text { month - } \\
3 \text { months - } \\
6 \text { months - } \\
1 \text { year - } \\
5-9 \text { years }\end{array}$ & $\begin{array}{l}\ldots \\
\ldots \\
\ldots \\
\ldots \\
\ldots \\
\ldots \\
\ldots\end{array}$ & $\begin{array}{l}628 \\
574 \\
444 \\
372 \\
297 \\
244 \\
198 \\
135\end{array}$ & $\begin{array}{r}0 \\
0 \\
0 \\
2 \\
1 \\
4 \\
4 \\
55 \\
106\end{array}$ & $\begin{array}{r}628 \\
574 \\
444 \\
371 \\
296 \\
241 \\
171 \\
74\end{array}$ & $\begin{array}{r}54 \\
130 \\
72 \\
73 \\
52 \\
42 \\
8 \\
9\end{array}$ & $\begin{array}{r}8 \cdot 6 \\
22 \cdot 6 \\
16 \cdot 2 \\
19 \cdot 7 \\
17 \cdot 6 \\
17 \cdot 5 \\
4 \cdot 7 \\
12 \cdot 1\end{array}$ \\
\hline
\end{tabular}

NotE:-The method of calculation is described in the text. 
of which the number of deaths during the interval (column 4) is expressed as a proportion (column 5). The death rates recorded in column 5 are somewhat irregular, but it must be remembered that the age intervals examined are of different lengths.

The age specific death rates from Table IV are used in Table $\mathrm{V}$ to give in life table form the estimated numbers of 1000 liveborn infants with congenital heart disease surviving to ages up to 10 years (shown in column 3). Of 1000 children alive at birth, 86 would be expected to die during the first day, leaving 914 alive at one day, of whom 207 would die during the remainder of the first week. Numbers alive at 1 month, 6 months, 1 year, and 10 years are 592, 391, 323, and 271 respectively.

We may now enquire to what extent these estimates are affected by the errors referred to above. Life expectation has been recalculated after $(a)$ removal of $\mathbf{4 0}$ from the number of deaths under one week, and $(b)$ addition of 42 to the number of children surviving to age 10 years (column 4).

TABLE V

Estimated Survival Rates of 1000 Liveborn Infants with Congenital Heart Disease

\begin{tabular}{|c|c|c|c|c|c|c|}
\hline \multirow{2}{*}{ Age period } & & \multirow{2}{*}{$\begin{array}{l}\text { Probability } \\
\text { of dying } \\
\text { during each } \\
\text { period } \\
\text { (1) }\end{array}$} & \multirow{2}{*}{$\begin{array}{l}\text { Number of } \\
\text { deaths during } \\
\text { each period } \\
\text { (2) }\end{array}$} & \multicolumn{2}{|c|}{$\begin{array}{l}\text { Number alive at beginning } \\
\text { of each period }\end{array}$} & \multirow{2}{*}{$\begin{array}{l}\text { Estimate* of incidence } \\
\text { per (thousand) in the } \\
\text { related population at } \\
\text { beginning of each period } \\
\text { (5) }\end{array}$} \\
\hline & & & & $\begin{array}{l}\text { Not adjusted } \\
\text { (3) }\end{array}$ & $\begin{array}{l}\text { Adjusted* } \\
\text { (4) }\end{array}$ & \\
\hline $\begin{array}{l}\text { Birth }- \\
1 \text { day - } \\
1 \text { week } \\
1 \text { month -.. } \\
3 \text { months - } \\
6 \text { months - } \\
1 \text { year - . } \\
5 \text { years - . . } \\
10 \text { years } . .\end{array}$ & $\begin{array}{l}. \\
. \\
\ldots \\
. . \\
. \\
. \\
. \\
. \\
.\end{array}$ & $\begin{array}{c}0.086 \\
0.226 \\
0.162 \\
0.197 \\
0.176 \\
0.175 \\
0.047 \\
0.121 \\
-\end{array}$ & $\begin{array}{r}86 \\
207 \\
115 \\
117 \\
84 \\
68 \\
15 \\
37 \\
-\end{array}$ & $\begin{array}{r}1000 \\
914 \\
707 \\
592 \\
475 \\
391 \\
323 \\
308 \\
271\end{array}$ & $\begin{array}{r}1000 \\
946 \\
771 \\
657 \\
541 \\
458 \\
390 \\
375 \\
346\end{array}$ & $\begin{array}{l}3.2 \\
3.0 \\
2.5 \\
2 \cdot 1 \\
1.8 \\
1.5 \\
1.3 \\
1 \cdot 2 \\
1 \cdot 1\end{array}$ \\
\hline
\end{tabular}

* See text for description of the method of adjustment.

These changes were of course suggested by the considerations discussed earlier in the examination of incidence. The data suggest that of 10 affected children born alive, 2 die by the end of the first week, between 3 and 4 by the end of the first month, and 6 by the end of the first year. Between 3 and 4 survive to the tenth birthday.

The adjusted survival rates have been used to calculate the incidence of children with congenital heart disease, which is expressed per 1000 children alive at the beginning of each period (column 5). For example, of 1000 children alive at birth, $3 \cdot 2$ are affected, as compared with $1 \cdot 1$ per 1000 children alive at 10 years. No allowance has been made for reduction in the related population because of deaths due to other causes, but the error that results is small.

\section{Associated Malformations}

In the present context we may consider briefly the frequency of association between malformation of the heart and other congenital malformations. For this purpose we have excluded the 145 cases recorded from the death register, for which data are incomplete. Table VI gives details of other malformations observed in $101(21 \%)$ of the remaining 488 subjects. The commonest association is with mongolism, which was exhibited by $31(6 \%)$ of the 488 cases. The nature of the heart lesion was known in 18 (of the 31 ); 14 were septal defects. The association of mongolism with atrial and ventricular septal defects was previously noted by Abbott (1927) and Silvy (1933).

Except in the case of mongolism there is no noteworthy association with any other single 
malformation. Nevertheless, the incidence of other defects, for example of the central nervous system or alimentary tract, is of course much higher in children with congenital heart disease than in the general population of births.

\section{TABLE VI}

Malformations associated with Congenttal Malformations of the Heart

\begin{tabular}{|c|c|c|c|c|c|c|c|c|c|}
\hline \multirow[b]{2}{*}{$\begin{array}{c}\text { Cardiac } \\
\text { malformation }\end{array}$} & \multicolumn{6}{|c|}{ Associated malformation } & \multirow{2}{*}{$\begin{array}{l}\text { Number } \\
\text { with } \\
\text { associated } \\
\text { malfor- } \\
\text { mations }\end{array}$} & \multirow{2}{*}{$\begin{array}{c}\text { Number } \\
\text { without } \\
\text { associated } \\
\text { malfor- } \\
\text { mations }\end{array}$} & \multirow[b]{2}{*}{ Total } \\
\hline & $\begin{array}{c}\text { Mongol- } \\
\text { ism }\end{array}$ & $\begin{array}{c}\text { Central } \\
\text { nervous } \\
\text { system } \\
\text { and special } \\
\text { senses }\end{array}$ & $\begin{array}{c}\text { Alimen- } \\
\text { tary } \\
\text { tract }\end{array}$ & Skeletal & $\begin{array}{l}\text { Genito- } \\
\text { urinary }\end{array}$ & Other & & & \\
\hline $\begin{array}{l}\text { Transposition of } \\
\text { great vessels }\end{array}$ & - & - & 2 & 1 (1) & $-(2)$ & - & 3 & 44 & 47 \\
\hline $\begin{array}{c}\text { Persistent common } \\
\text { arterial trunk }\end{array}$ & - & 1 & 3 & 1 (1) & $-(1)$ & 1 & 6 & 11 & 17 \\
\hline Pulmonary stenosis. . & - & 1 & $2(1)$ & 2 & $2(1)$ & 1 & 8 & 34 & 42 \\
\hline Coarctation of aorta & - & - & 1 & $-(1)$ & 3 & 1 (1) & 5 & 27 & 32 \\
\hline Septal defects & 14 & 3 & 4 (4) & 5 (2) & $5(3)$ & $3(2)$ & 34 & 87 & 121 \\
\hline $\begin{array}{l}\text { Patent ductus } \\
\text { arteriosus .. }\end{array}$ & 1 & 2 & - & $-(2)$ & 1 & 2 & 6 & 56 & 62 \\
\hline $\begin{array}{c}\text { Other specified } \\
\text { defects } \quad . .\end{array}$ & 3 & $-(1)$ & 6 & $-(2)$ & - (1) & 5 (4) & 14 & 37 & 51 \\
\hline $\begin{array}{l}\text { Defects not } \\
\text { specified } \ldots\end{array}$ & 13 & 3 & 3 (1) & 5 (2) & - & 1 & 25 & 91 & 116 \\
\hline Total & 31 & $10(1)$ & 21 (6) & $14(11)$ & $11(8)$ & 14 (7) & 101 & 387 & 488 \\
\hline
\end{tabular}

In brackets are the numbers of individuals exhibiting a particular associated malformation who have been classified under other associated abnormalities.

\section{Sex RATIO}

Of the 633 patients $338(53 \%)$ were males. The numbers of each sex are recorded in Appendices $A$ and $B$ according to type, and sex ratios (expressed as the percentage of males) are given for the main groups in Table VII. For this purpose we have combined patients diagnosed post mortem and by consultant examination, since sex ratios of cases confirmed by the two methods are fairly consistent. The results are compared with those of Abbott (1936). Except in the case of patent ductus arteriosus, sex ratios for the various classes of malformation are different in the two series; but it must be remembered that numbers are rather small, and that Abbott's material can by no means be regarded as representative.

Sex ratios slightly above 50 have generally been reported in series of grouped congenital heart defects, for example by Leech (1935), Abbott (1936), Roberts (1937), Gibson and Clifton (1938), Ash and Harshaw (1939), Rauh (1939), and Campbell (1949). Brown (1939) reported 300 cases among which there was a slight excess of females.

\section{SUMmary}

An attempt has been made to obtain information about all cases of congenital heart disease born to Birmingham mothers in the years 1940-49. In a population of 194,418 total births 633 
TABLE VII

SeX Ratios for Specific Cardiac Malformations

\begin{tabular}{|c|c|c|c|c|c|}
\hline \multirow{2}{*}{\multicolumn{2}{|c|}{ Malformation }} & \multicolumn{2}{|c|}{ Birmingham 1940-49 } & \multicolumn{2}{|c|}{$\begin{array}{c}\text { Date recorded by Abbot } \\
(1936)\end{array}$} \\
\hline & & $\begin{array}{l}\text { Number } \\
\text { of cases }\end{array}$ & $\begin{array}{l}\text { Percentage } \\
\text { of males }\end{array}$ & $\begin{array}{l}\text { Number } \\
\text { of cases }\end{array}$ & $\begin{array}{l}\text { Percentage } \\
\text { of males }\end{array}$ \\
\hline \multicolumn{2}{|c|}{ 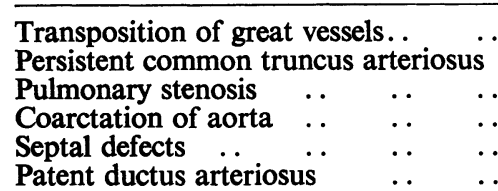 } & $\begin{array}{r}47 \\
17 \\
42 \\
32 \\
121 \\
62\end{array}$ & $\begin{array}{l}72 \\
47 \\
69 \\
44 \\
55 \\
39\end{array}$ & $\begin{array}{r}81 \\
21 \\
150 \\
87 \\
122 \\
105\end{array}$ & $\begin{array}{l}52 \\
52 \\
50 \\
71 \\
46 \\
34\end{array}$ \\
\hline
\end{tabular}

affected were identified. Diagnosis was confirmed at necropsy (236) or operation for patent ductus arteriosus (19) or by a consultant physician (223). In the remainder the diagnosis depended upon the report of the school medical officer (10) or certification of cause of death (145).

Incidence during the whole period was 3.17 per thousand total births, and 3.23 per thousand live births. For the years 1940-44, when ascertainment was more complete than in later years, incidence was 3.62 per thousand total births and 3.73 per thousand live births.

Estimates of life expectation at birth suggest that of 10 affected children born alive, 2 die by the end of the first week, between 3 and 4 by the end of the first month, and 6 by the end of the first year. Between 3 and 4 survive to the tenth birthday.

Associated abnormalities were observed in $101(21 \%)$ of 488 cases. Thirty-one were mongols. Of 18 mongols in which the nature of the heart lesion was known, 14 had septal defects. There was no noteworthy association between congenital heart disease and any other single malformation.

Sex ratios are recorded for various types of malformation.

For facilities in the collection of case records, we are indebted to the following: (1) The staff of the Birmingham Children's Hospital, in particular Dr. Clifford Parsons who made available the records of the congenital heart clinic; (2) The staffs of all other Birmingham hospitals, in particular of Selly Oak and Dudley Road Hospitals; (3) Dr. H. S. Baar, Dr. W. Whitelaw, and other hospital pathologists for access to post-mortem material; (4) Dr. H. M. Cohen, Dr. M. E. Lemin, and their assistant school medical officers for organizing and executing an inquiry into the numbers of cases of congenital heart disease among school children; (5) Dr. Jean Mackintosh and the staff of the Maternity and Child Welfare Department for free access to departmental records.

We are grateful to Dr. Audrey Heywood, who assisted in the analysis of the data.

\section{REFERENCES}

Abbott, M. E. (1927). Nelson's Loose-Leaf Living Medicine. 4, 207.

(1936). Atlas of Congenital Cardiac Disease. American Heart Association, New York.

Ash, R., and Harshaw, E. (1939). Amer. Heart J., 18, 80.

Benn, J. (1947). Brit. Heart J., 9, 283.

Brown, J. W. (1939). Congenital Heart Disease. John Bale, London.

Browne, F. J. (1924). Edin. med. J., 83, 158.

Campbell, M. (1949). Quart. J. Med., 18, 379.

DePorte, J. V., and Parkhurst, E. (1945). N.Y. State J. Med., 45, 1097.

Evans, M., and Smith, G. S. (1946). J. Obstet. Gynee. Brit. Emp., 53, 440.

Gibson, S., and Clifton, W. M. (1938). Amer. J. Dis. Child., 55, 761.

Jacobius, H. L., and Moore, R. A. (1938). J. tech. Meth., 18, 133.

Leech, C. B. (1935). J. Pediat., 7, 802.

MacMahon, B. (1952). Brit. J. soc. Med., 6, 178.

Malpas, P. (1937). J. Obstet. Gynac. Brit. Emp., 44, 434.

Morison, J. E. (1952). Fatal and Neonatal Pathology. Butterworth \& Co., London.

Potter, E. L. (1938). Arch. Path., 25, 607.

(1940). J. Amer. med. Ass., 115, 996.

Rannels, H. W., and Propst., J. H. (1937). J. tech. Meth., 17, 113.

Rauh, L. W. (1939). Amer. Heart J., 18, 705. 
Roberts, J. T. (1937). J. tech. Meth., 17, 108.

Sampson, J. J., Christie, A., and Geiger, J. C. (1938). Amer. Heart J., 15, 661.

Silvy, M. (1934). Mongolisme et Malformations Cardiaques. Paris. Cited by Brown, J. W. (1939).

Thordarson, O. (1947). Acta. Med. Scand., 127, 233.

Weiss, M. M. (1941). Amer. Heart J., 22, 112.

\section{APPENDIX A}

Diagnosis in 255 Patients Examined Post Mortem or at Operation for Patent Ductus Arteriosus

1. Transposition of Great Vessels

(a) with ventricular septel defect 1

(b) with cor triloculare ${ }^{2}$

(c) with no ventricular septal defect

(d) state of septum unknown

(e) right-sided aorta with ventricular septal defect

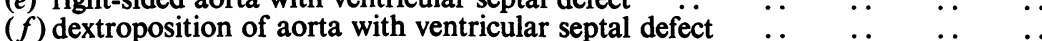

$(g)$ various ${ }^{4}$..

2. Persistent Common Truncus Arteriosus

(a) with cor biloculare (3) or single ventricle (1)

(b) from left ventricle with ventricular septal defect

(c) from right ventricle with septal defect and rudimentary left ventricles $\quad \cdots \quad \cdots$

\begin{tabular}{rrr}
6 & 4 & 10 \\
1 & 1 & 2 \\
8 & 1 & 9 \\
6 & 1 & 7 \\
2 & 1 & 3 \\
3 & -1 & 3 \\
3 & 1 & 4 \\
\hline 29 & 9 & 38
\end{tabular}

3. Pulmonary Stenosis

$\begin{array}{llllllllll}\text { (a) with ventricular septal defect }(3)^{6} \text { or single ventricle (2) } & \ldots & \ldots & \ldots & \ldots \\ \text { (b) Fallot's tetralogy } & \ldots & \ldots & \ldots & \ldots & \ldots & \ldots & \ldots & \ldots & \ldots\end{array}$

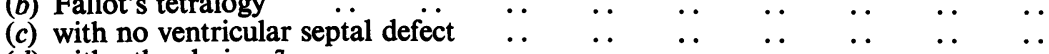

(d) with other lesions?

4. Coarctation of Aorta

(a) with patent ductus arteriosus 8

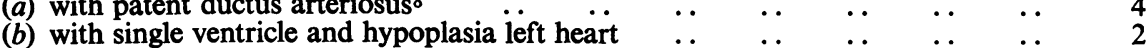

(c) complete atresia (8) or non-development (6) of arch of aorta $\quad \ldots \quad$. $\quad \ldots \quad \ldots \quad 4$

5. Septal Defects

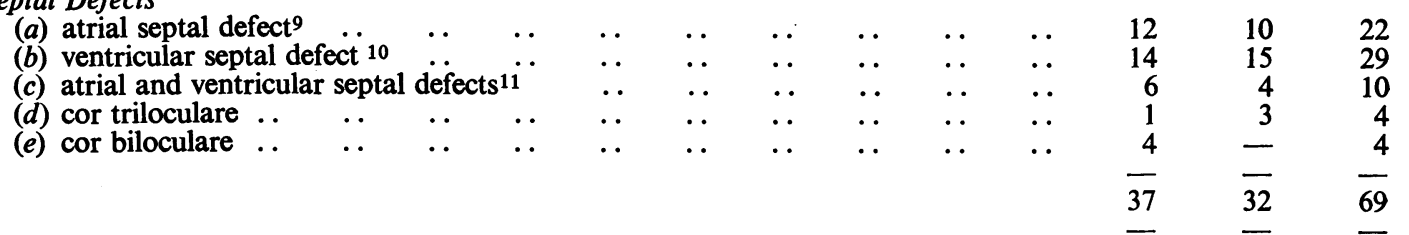

6. Patent Ductus Arteriosus

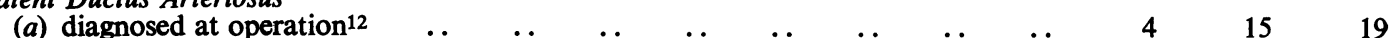

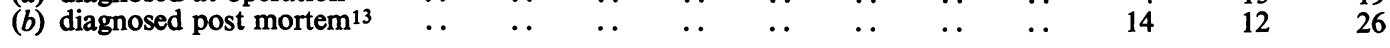

7. Other defects

$\begin{array}{lllllllllllll}\text { (a) patent foramen ovale } \ldots & \ldots & \ldots & \ldots & \ldots & \ldots & \ldots & \ldots & \ldots & 10\end{array}$

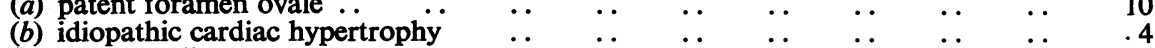

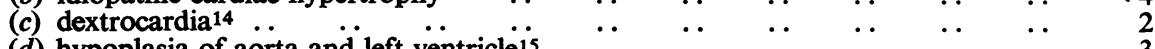

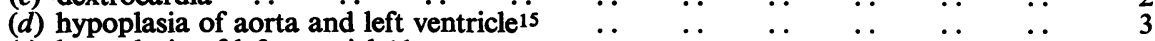

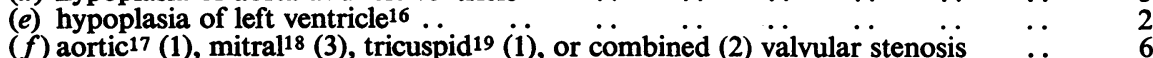

$\begin{array}{llllll}\text { (f) aortic17 (1), } \text { mitral }^{18}(3), \text { tricuspid19 }^{19}(1) \text {, or combined (2) valvular stenosis } & \ldots & 6 \\ (g) \text { fotal endocarditis } & \end{array}$

(h) pulmonary veins opening into separate chamber- $\ddot{-}$ no connection with auricles or ventricles

$\begin{array}{lll}\overline{29} & \frac{1}{10} & \frac{1}{39}\end{array}$




\section{Notes to APPENDix A}

1 One with tricuspid atresia; one with single atrium; one with atrial septal defect and atresia of aorta between 4th and 6th left arches.

2 One with atrial septal defect.

3 One with slight coarctation of aorta.

4 One with over-riding aorta, pulmonary artery from left ventricle and pulmonary stenosis; one with complete transposition with descending aorta from pulmonary artery through patent ductus (i.e. from left ventricle); one with aorta from right ventricle and absent pulmonary artery; one with cor biloculare and pulmonary stenosis.

5 One with absent arch of aorta.

6. One with bicuspid aortic valves.

7 One with reduplication of pulmonary artery; one with hypoplasia of right heart; three with endocarditis.

8 One with biscuspid aortic valve.

9 Four with widely patent ductus arteriosus.

10 One with malformation of pulmonary and mitral valves; one with tricuspid fotal endocarditis; one with hypoplasia of aorta; one with " absent pulmonary valves "; one with hypoplasia of LV. and biscuspid aortic valve.

11 Three with malformation of tricuspid or mitral valve; one with hypoplasia of aorta.

12 Two with suspected additional lesions.

13 Seven with widely patent foramen ovale.

14 One with cor triloculare and VSD; one with cor biloculare and hypoplasia of pulmonary artery.

15 Two with fotal endocarditis.

16 One with transverse septum in left at:ium; one with absent right pulmonary vessels.

17 With bicuspid aortic valve.

18 One with atrial and ventricular septal defects.

19 With rudimentary left atrium.

20 One with bicuspid aortic and pulmonary valves.

APPENDIX B

Provisional Diagnosis in 117 of 223 Patients examined by Consultants

1. Transposition of great vessels

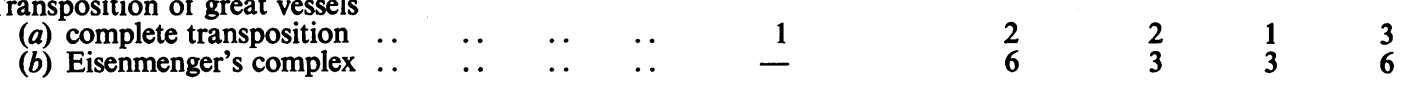

2. Persistent common arterial trunk

3. Pulmonary stenosis

$\begin{array}{llllll}\text { (a) Tetralogy of Fallot } \quad \ldots & \ldots & \ldots & \ldots & 12\end{array}$

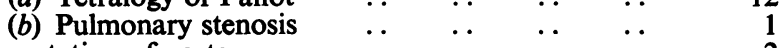

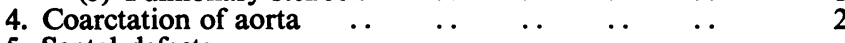

Full Partial

5. Septal defects

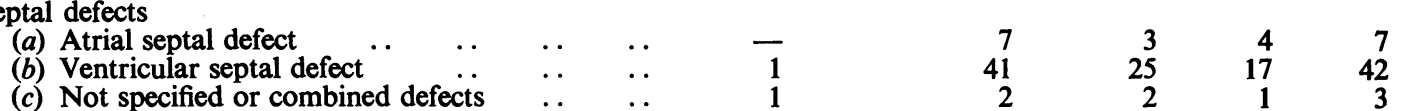

6. Patent ductus arteriosus

\begin{tabular}{|c|c|c|c|c|c|c|c|c|c|}
\hline (a) Alone With other deft. & $\because$ & $\cdots$ & $\cdots$ & * & E & 14 & 5 & 9 & $\begin{array}{r}14 \\
3\end{array}$ \\
\hline $\begin{array}{l}\text { (b) Witn otner derects } \\
\text { her defects }\end{array}$ & .. & . & . & . & & & & & \\
\hline (a) Dextrocardia 1 & .. & . & . & 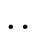 & 4 & - & 1 & 3 & 4 \\
\hline (b) Heart block ${ }^{2}$ & . & . & . & .. & 5 & $\overline{2}$ & 5 & 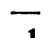 & 5 \\
\hline (c) Sub-aortic stenosis & .. & .. & . & . & - & 3 & 2 & 1 & 3 \\
\hline Total & .. & .. & .. & . & 28 & 89 & 67 & 50 & 117 \\
\hline
\end{tabular}

1 Two with other defects

2 Four with other defects.

* Includes angiogram and cardiac catheterization where appropriate.

$\dagger$ Includes X-ray and electrocardiogram. 